\title{
POSSIBILITIES OF USING GRAPE MARC FOR MAKING FUEL PELLETS
}

\author{
Patrik Burg, Vladimir Masan, David Ludin \\ Mendel University in Brno, Czech Republic \\ patrik.burg@mendelu.cz
}

\begin{abstract}
The paper called 'Possibilities of using grape marc for making fuel pellets' is focused on the topic of efficient usage of grape marc as a renewable energy source. From a global point of view, grapevine pressings, a byproduct of the wine industry, present a significant source of biomass. The organisation Internetionale de la Vignet et du Vin (OIV) estimates that there are over 66.5 mil. tons of grapevines manufactured globally, from which 38 mil. tons in Europe. This means that only in European conditions, there are approximately 8 mil. tons of grape pomace produced. Empirical measurements took place in the years 2013-2015 at grape marc samples from viniculture subjects in the wine-growing area Morava. The results of this paper are divided into two main parts - grape marc usage for energy purposes and for pellet production. There was implemented a wide range of calorimetrical measurements of combustion heat and caloric power of grape marc in its original state, grape marc after seed separation (assumption of oil pressing usage), and in seeds themselves. The results indicate that the heating power varies between $16.07-21.14 \mathrm{MJ} \cdot \mathrm{kg}^{-1}$. The highest heating power values were stated by seeds and grape marc in its original state. It could be presumed that the main reason is rather high oil component in grapevine seeds. Moreover, the measurement set was supplemented by results focused on grape marc usage for pellet production. Different proportions of dried grape marc combined with wine shoots and hay were used as the input materials. The measured values imply that the highest heating power $\left(19.22 \mathrm{MJ} \cdot \mathrm{kg}^{-1}\right)$ was obtained from pellets composited from $60 \%$ grape marc, $20 \%$ wine shoots, and $20 \%$ hay. Their apparent density is $630.9 \mathrm{~kg} \cdot \mathrm{m}^{-3}$. The produced pellets correspond with the norm CSN EN 15210-2 from the perspective of mechanical ruggedness.
\end{abstract}

Keywords: grapevine, grape pomace, calorific value, grape pomace pelletizing.

\section{Introduction}

On a global scale, grapevine is grown on the area of 7,519,000 hectares. Spain has the largest area of vineyards in Europe - 1,000,000 ha, France - 800,000 ha, Italy - 769,000 ha and Portugal 239,000 ha [1].

The production of grape and its processing in the production of wine is closely related to the production of grape marc. During compressing of $1,000 \mathrm{~kg}$ of grapes, in the processed product, there are contained stems in the amount of $40-60 \mathrm{~kg}$, grape marc in the amount of $230-300 \mathrm{~kg}$, the rest is pressed must. Marc itself consists of remnants of pulps, peels, seeds and in some cases even of stems, which together represent approximately one quarter of the mass of grapes [2]. Schieber et al., Baydar et al. and Rubio et al. [3-5] also state that from the total quantity of processed grapes, the share of marc creates, depending on the variety, degree of ripeness, used pressing equipment, quantity of pressing cycles, up to $15-25 \%$ of the volume weight $400-800 \mathrm{~kg} \cdot \mathrm{m}^{-3}$ and moisture between 30 to $50 \%$.

Legislative regulations of the EU and increasingly stricter regulations of the Czech Republic in the field of waste management lead to searching of new waste-free technologies, which would provide effective and efficient use of waste products from production processes [6]. In terms of waste management, marc represents secondary biotic waste produced in the sector Food-Drink-Milk, which cannot be disposed to municipal waste landfills [7].

In the past few years, in central European conditions, the attention has been focused on possibilities of effective utilization of marc as an energy source for direct combustion or as an input material for biogas plants.

There is available a large amount of literature sources about the calorific value of materials from the wine production, e.g., grapevine, which is stated in the works of [8; 9]. However, in relation to grape marc, these data appear quite sporadically [10].

The objective of the work is to determine the combustion heat and calorific value of grape marc by the calorimetric method, including evaluation of its use in the production of pellets. 


\section{Materials and methods \\ Grape marc of evaluated varieties}

The subject of the research was grape marc from selected must varieties of grapevine. With regard to the varietal composition of vineyards in the Czech Republic, there were selected varieties with the highest proportion of plantations, in which we can assume their real use in the operational practice. With regard to the varietal composition in cooperating subjects, there was carried out collection and analysis of grape marc samples in the years 2013-2015 of the following varieties: Grüner Veltliner (VZ), Müller Thurgau (MT), Rhine Riesling (RR), Welschriesling (RV), St. Laurent (SV), Blaufränkisch (FR), Zweigeltrebe (ZW) and Blauer Portugieser (MP).

\section{Determination of the energy value of grape marc}

The energy value of grape marc was verified by a set of calorimetric measurements in order to determine the combustion heat and calorific value. These measurements were carried out in grape marc in the original condition, grape marc after separation of seeds (intended to be used for oil extraction) and grape seeds themselves, always in triplicate.

The determination of the combustion heat for solid biofuels was carried out according to the standard CSN P CEN/TS 14918. The prerequisite of determination is the analysis of elementary composition, which was provided through the TOC/TN analyser multi N/C 2100S and the gas chromatograph Trace GC ultra. In all analysed samples, there was simultaneously determined dry mass according to the standard CSN EN 14346.

For the determination of the calorific value, there was used the calorimeter Anton Parr 6400, for the accurate determination of the weight of a combusted sample there was used the analytical weighting machine Ohaus Adventurer Pro AV264C. The obtained combustion heats were in accordance with CSN ISO 1928 calculated to the calorific value according to formula 1.

$$
Q^{r}{ }_{i}=Q^{r}{ }_{s}-\gamma \cdot\left(W_{t}^{r}+8,94 \cdot H_{t}^{r}\right),
$$

where $Q_{i}^{r}$ - calorific value of the evaluated sample, $\mathrm{MJ} \cdot \mathrm{kg}^{-1}$;

$Q^{r}$ - gross heating value of the original sample, $\mathrm{MJ} \cdot \mathrm{kg}^{-1}$;

$\gamma$-ratio of evaporation of $1 \% \mathrm{H}_{2} \mathrm{O}, \mathrm{MJ} \cdot \mathrm{kg}^{-1}$, at temperature $25^{\circ} \mathrm{C}, \gamma=0,02442 \mathrm{MJ} \cdot \mathrm{kg}^{-1}$;

8.94 - hydrogen to water conversion ratio;

$W_{t}^{r}$ - total water content in the original sample, \%;

$H^{r}{ }_{t}-$ total hydrogen content in the original sample, $\%$.

\section{Use of grape marc for the production of pellets}

The production of pellets was carried out on the pelletizing line MGL 400. For purposes of the experiments, there were selected three input materials, i.e. grape marc (humidity 10\%), grape cane (humidity $11 \%$ ), and hay (humidity $15 \%$ ). These materials were mixed together to form a mixture with various percentage of grape marc:

- Variant 1 (60\% grape marc, $20 \%$ grape cane and $20 \%$ hay);

- Variant 2 (50\% grape marc, $25 \%$ grape cane and $25 \%$ hay);

- Variant 3 (40\% grape marc, $30 \%$ grape cane and $30 \%$ hay).

For the pellets made in this way, there was carried out the determination of mechanical ruggedness, apparent density, combustion heat and the calorific value.

By the mechanical ruggedness, there is measured shock proofness of pellets and attrition resistance caused by handling and transport. During manipulation of pellets, there may occur the formation of fragments and dust particles, which may lead to unstable combustion and due to the formation of dust particles, there increases the risk of explosion.

During testing, a pellet sample is subjected to controlled bumping by mutual smashing of pellets to chamber walls in a defined rotating testing drum. From the weight of the sample remaining after the separation of abraded and firmly shredded particles, there is calculated the mechanical ruggedness according to formula 2 . 


$$
M_{O}=\frac{M_{P}}{M_{K}} \cdot 100,
$$

where $M_{o}$ - mechanical ruggedness, \%;

$M_{p}$ - weight of sieved pellets before rotating in a drum, g;

$M_{k}$ - weight of sieved pellets after rotating in a drum, g.

The apparent density, together with the calorific value, is used for the determination of the energy density. In practice, it enables to evaluate the required storability and space requirements during transportation. The determination of apparent density is carried out according to CSN P CEN/TS 15103. It is determination of the weight of biomass after pouring into a standard container and weighting. The apparent density is expressed in $\mathrm{kg} \cdot \mathrm{m}^{-3}$.

\section{Results and discussion}

In Table 1, there are stated mean values of elementary composition of the evaluated samples of grape marc and seeds from white and blue must varieties of grapevine, which were used for the determination of the calorific value from the combustion heat.

Mean values of elementary composition of grape marc and seeds

Table 1

\begin{tabular}{|c|c|c|c|c|c|c|}
\hline \multirow{2}{*}{ Evaluated samples } & \multicolumn{7}{|c|}{ Mean values of observed attributes } \\
\cline { 2 - 7 } & $\mathbf{C , \%}$ & $\mathbf{H , ~ \%}$ & $\mathbf{O ,} \%$ & $\mathbf{N}, \boldsymbol{\%}$ & $\mathbf{S ,} \%$ & ash, \% \\
\hline Grape marc - white varieties & 52.9 & 5.82 & 34.24 & 0.55 & 4.12 & 2.25 \\
\hline Grape marc - blue varieties & 41.34 & 5.95 & 44.91 & 0.67 & 3.37 & 3.51 \\
\hline Grape seeds - mixture & 51.55 & 5.97 & 38.42 & 1.47 & 3.96 & 1.92 \\
\hline
\end{tabular}

In Figure 1, there are stated the average calorific values for the two-year period, which were calculated in accordance with CSN ISO 1928, based on the determined values of combustion heat in the evaluated samples of grape marc in the original state, grape marc after separation of seeds and seeds themselves.

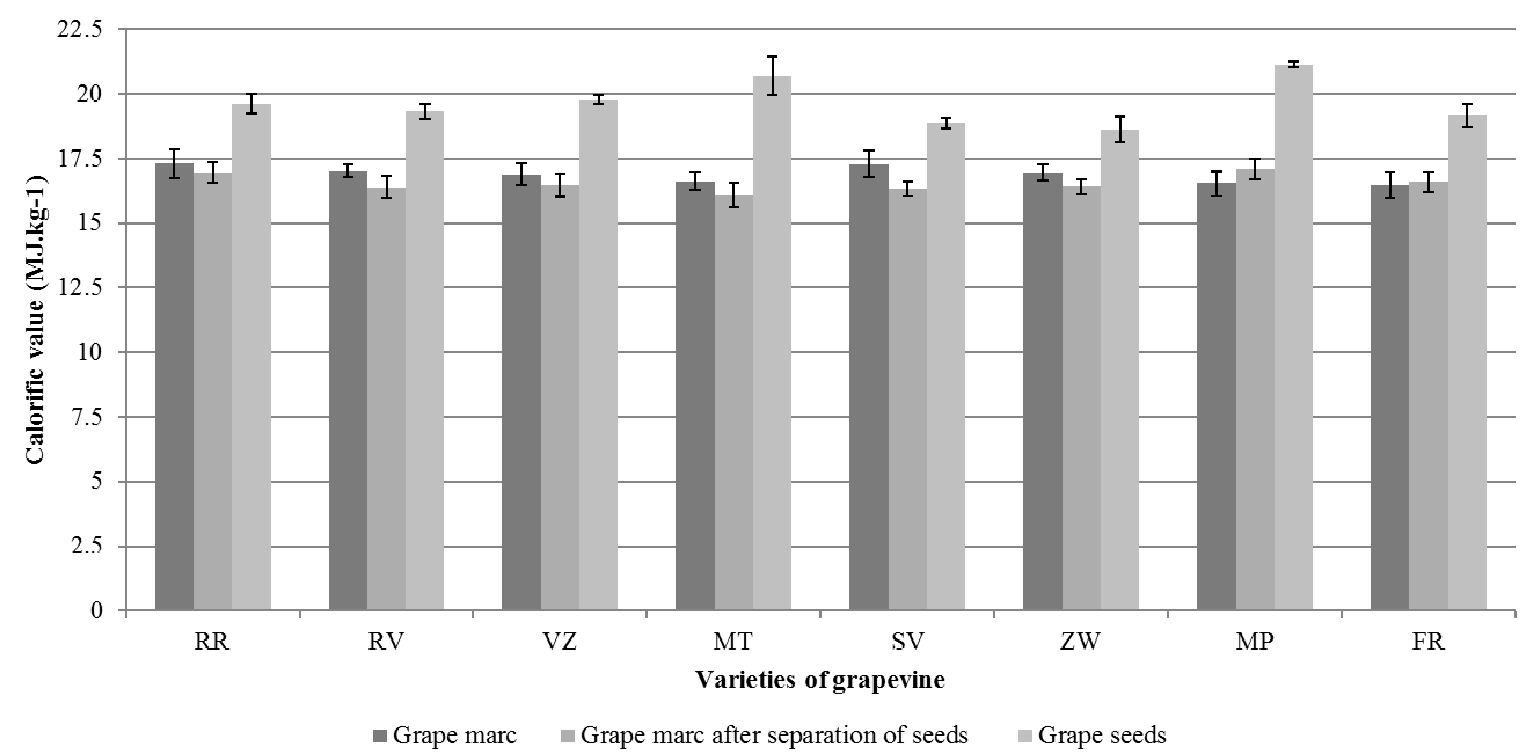

Fig. 1. Calorific values in evaluated samples

Figure 1 implies that the highest calorific values were determined in seeds themselves, where the maximum was reached by the variety Blauer Portugieser $21.14 \mathrm{MJ} \cdot \mathrm{kg}^{-1}$. Conversely, the lowest calorific values were determined for grape marc after separation of seeds, where it reached the value 16.07 MJ $\mathrm{kg}^{-1}$ in the variety Müller Thurgau.

It is clear from the data about the calorific value of grape marc carried out in the previous measurements, that it is a material with a very good calorific value, which is comparable with the 
calorific values of, e.g., cereals (18.00 MJ $\left.\cdot \mathrm{kg}^{-1}\right)$ or brown coal $\left(18.10 \mathrm{MJ} \cdot \mathrm{kg}^{-1}\right)$, it even exceeds the calorific value of wood chips $\left(12.50 \mathrm{MJ} \cdot \mathrm{kg}^{-1}\right)$ and wood $\left(14.60 \mathrm{MJ} \cdot \mathrm{kg}^{-1}\right)$. Annamalai et al. [11] also state calorific values of grape marc at the level $20.34 \mathrm{MJ} \cdot \mathrm{kg}^{-1}$. Available literature sources imply that in countries with developed viniculture, there are verified methods of grape marc use in the production of briquettes and pellets. The main problem in these technologies is high humidity of grape marc. For example in Italy, this state is solved by natural drying of grape marc under ventilated sheds. In Germany, there appear references about the use of waste heat from biogas plants or equipment for regulation of temperature during fermentation. In the Czech Republic, this technology has not been solved yet.

For these reasons, the latter part of the experimental measurement was oriented to the production of pellets from crushed grape cane, hay and grape marc in varying percentage representation. All measurements were performed in the year 2015 in an accredited laboratory of MENDELU in Brno. During testing of the mechanical ruggedness, the pellets were weighted according to the applicable methodology, sieved and inserted into a testing drum, where mechanical abrasion occurred. There were always three samples of pallets from each experimental variant tested. Table 2 states the obtained results, which were compared to the limit value, which is stated by the Czech standard CSN EN 15210-2.

Table 2

Values of mechanical ruggedness of pellets

\begin{tabular}{|c|c|c|}
\hline $\begin{array}{c}\text { Pellets - material } \\
\text { composition }\end{array}$ & $\begin{array}{c}\text { Average value of } \\
\text { mechanical ruggedness, \% }\end{array}$ & $\begin{array}{c}\text { Limit value of mechanical } \\
\text { ruggedness according to CSN } \\
\text { EN 15210-2, \% }\end{array}$ \\
\hline Variant 1 & 96.82 & \multirow{2}{*}{96.50} \\
\hline Variant 2 & 96.69 & \\
\hline Variant 3 & 96.15 & \\
\hline
\end{tabular}

According to the standard CSN EN 15210-2 Solid biofuels - specification and fuel classes part 2: wood pellets for non-industrial use, there is permitted the mechanical ruggedness of $96.5 \%$. The results imply that the variants 1 and 2 meet this condition, where the values of mechanical ruggedness range between 96.69-96.82\%. Only the variant 3 with the lowest share of grape marc did not meet the requirement of the standard $(40 \%)$, where the values of mechanical ruggedness amounted to $96.15 \%$.

Benetto et al. [12] state that grape marc is responsible for better adhesion of pellets and it also prevents disintegration of the material in the process of pressing thanks to the pulp content in peels. Miranda et al. [13] state that with an increasing share of grape marc in pellets, there is a decreasing share of ash. On the other hand, pellets with a higher proportion of grape marc show higher values of fixed carbon [14].

In Table 3, there are stated average values of apparent density of the evaluated pellet samples.

Table 3

Values of apparent volume density

\begin{tabular}{|c|c|c|}
\hline $\begin{array}{c}\text { Pellets - material } \\
\text { composition }\end{array}$ & $\begin{array}{c}\text { Average value of apparent } \\
\text { density, } \mathbf{~ k g} \cdot \mathbf{~ m}^{-3}\end{array}$ & Standard deviation \\
\hline Variant 1 & 630.90 & 15.90 \\
\hline Variant 2 & 621.37 & 3.57 \\
\hline Variant 3 & 619.27 & 3.16 \\
\hline
\end{tabular}

As the results of measuring imply, the apparent density ranged between $619.27-630.90 \mathrm{~kg} \cdot \mathrm{m}^{-3}$. For example, Larsson, Rudolfsson [15] state that an important parameter of pellets from the perspective of their requirements for storage is apparent density, which usually ranges between 550$750 \mathrm{~kg} \cdot \mathrm{m}^{-3}$.

In Table 4, there are stated the calorific values of the pellets according to individual variants.

The results show that the highest calorific value $\left(19.22 \mathrm{MJ} \cdot \mathrm{kg}^{-1}\right)$ is produced by the pellets of the variant 1 , which consist by $60 \%$ of grape marc, $20 \%$ of grape cane and by $20 \%$ of hay, conversely, 
the pellets of the variant 3 have the lowest calorific value $\left(17.36 \mathrm{MJ} \cdot \mathrm{kg}^{-1}\right)$, which consist by $40 \%$ of grape marc, $30 \%$ of grape cane and $30 \%$ of hay. Thus, based on the results, there is the evident influence of grape marc share on the calorific values of the evaluated pellet variants. A statistically significant difference at the chosen level of significance $(\alpha=0.05)$ was proved between the variant 1 and the variant 3, as stated in Fig. 2.

Table 4

Calorific values of pellets

\begin{tabular}{|c|c|c|c|c|c|}
\hline \multirow{2}{*}{$\begin{array}{c}\text { Pellets - } \\
\text { material } \\
\text { composition }\end{array}$} & \multicolumn{5}{|c|}{ Calorific value, MJ.kg-1 } \\
\cline { 2 - 6 } & $\mathbf{1}^{\text {st }}$ repeating & $\mathbf{2}^{\text {nd }}$ repeating & $\mathbf{3}^{\text {rd }}$ repeating & Average & $\begin{array}{c}\text { Standard } \\
\text { deviation }\end{array}$ \\
\hline Variant 1 & 19.21 & 19.39 & 19.05 & 19.22 & 0.34 \\
\hline Variant 2 & 18.06 & 18.05 & 18.98 & 18.37 & 0.10 \\
\hline Variant 3 & 17.49 & 17.58 & 17.01 & 17.36 & 0.06 \\
\hline
\end{tabular}

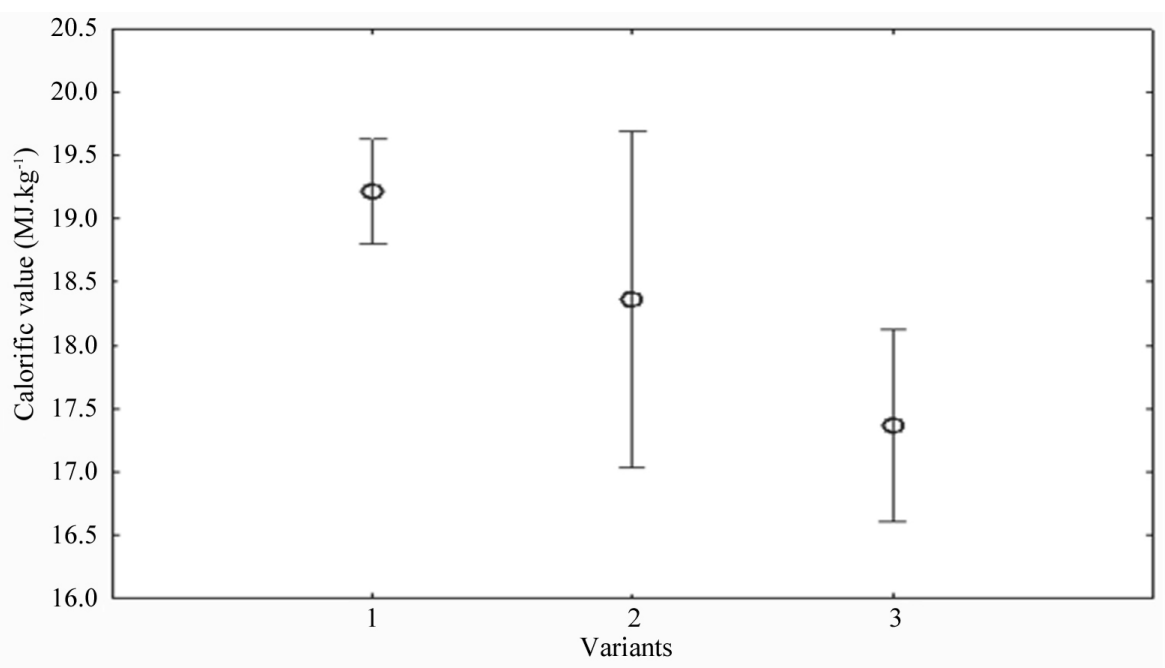

Fig. 2. Results of ANOVA evaluation of the calorific value of pellets

For example, Prozil et al. [16] carried out determination of the calorific value of pallets made of grape stems. The results of his measurement imply that these pellets had the calorific value 16.7 MJ $\cdot \mathrm{kg}^{-1}$. McCormick, Kåberger and Freppaz et al. [17; 18] dealt with the issue of energy use in various alternative sources of energy. The results of their work imply that the calorific value of pellets from fast growing trees was around $18.5 \mathrm{MJ} \cdot \mathrm{kg}^{-1}$, pellets from crop biomass at the level of $16 \mathrm{MJ} \cdot \mathrm{kg}^{-1}$, pellets from peat at the level of $20.3 \mathrm{MJ} \cdot \mathrm{kg}^{-1}$ and pellets from pomace $14.2 \mathrm{MJ} \cdot \mathrm{kg}^{-1}$. Souček et al. [8] dealt with the evaluation of the calorific value of another waste product of vineyard production, which is grape cane obtained from winter cutting of vineyard with humidity under $10 \%$. The calorific values of individual varieties were stated in a range from $14.39-16.66 \mathrm{MJ} \cdot \mathrm{kg}^{-1}$.

\section{Conclusions}

1. The energetic value of grape marc was verified by a set of calorimetric measurements, in which there were stated the values of combustion heat and calorific values. Thanks to the obtained results, there was confirmed the hypothesis about high calorific values of grape marc. Depending on the nature of the tested sample - grape marc in the original state, grape marc after separation of seeds and seeds themselves, it ranged between 16.07-21.14 MJ $\mathrm{kg}^{-1}$.

2. The conducted measurement showed the possibility of usage of grape marc together with other kinds of input materials (hay, grape cane) for the production of pellets.

3. In testing of mechanical ruggedness of pellets, the variant 3 did not meet the limit value $96.50 \%$ according to CSN EN 15210-2, consisting by $40 \%$ of grape marc, $30 \%$ of grape cane and $30 \%$ of hay.

4. The values of apparent density in all three experimental variants ranged between 619.27$630.90 \mathrm{~kg} \cdot \mathrm{m}^{-3}$ 
5. For the pellet samples, there was determined the calorific value ranging between $17.36 \mathrm{MJ} \cdot \mathrm{kg}^{-1}$ in the variant 3 , to $19.22 \mathrm{MJ} \cdot \mathrm{kg}^{-1}$ in the variant 1 . Between these variants, there was carried out the variance analysis at the level of significance $(\alpha=0.05)$, which proved a statistically significant difference.

\section{Acknowledgements}

The results are based on the solution of the research project IGA ZF MENDELU IGA-ZF/2017AP003.

\section{References}

1. OIV. Internationaler Kodex der önologischen Praxis. 2nd Ed. Organisation Internetionale de la Vignet et du Vin. German. 2009. 160 p. (in German).

2. Hugh J. Der große Johnson: die Enzyklopädie der Weine, Weinbaugebiete und Weinerzeuger der Welt. 15. Aufl. München: Hallwag, 2002. ISBN 3774251517. (in German).

3. Schieber A., Stintzing F.C., Carle R. By-products of plant food processing as a source of functional compounds- recent developments. Trends in food science and technology, vol. 12, 2001, pp. 401-415.

4. Baydar N.G., Özkan G., Çetin E.S. Characterization of grape seed and pomace oil extracts. Grasas y aceites, vol. 58, 2007, pp. 29-33.

5. Rubio M., Álvarez-Orti M., Pardo J.E. A review on the utilization of grape seed oil as an alternative to conventional edible vegetable oils. La rivista italiana delle sostanze grasse, vol. 84, 2009, pp. 121-129.

6. Boulton R.B., Singleton V.L., Bisson F.L., Kunkee R.E. Principles and practices of winemaking. New York: Springer+Business Media, 2010. ISBN 9781441951908.

7. Environment Protection Authority. Consultancy report: Opportunities for the reuse of winery industry solid wastes, SA Waste Management Committee, PPK Environment \& Infrastructure Rty Ltd, 17 January 2001.

8. Souček J., Burg P. Stanovení výhřevnosti u štěpky réví z vinic. Acta Universitatis agriculturae et silviculturae Mendelianae Brunensis, vol. 58, 2010, pp. 185-190. (in Czech).

9. Michálek M., Burg P., Zemánek P. The assessment of the suitability and effectiveness of the technologies for vineyard wood waste utilization for energetic purposes. Acta Universitatis Agriculturae et Silviculturae Mendelianae Brunensis, vol. 61, 2013, pp. 157-162.

10. Walg O. Taschenbuch der Weinbautechnik. 2. Aufl. Mainz: Fraund, 2007. ISBN 9783921156780. (in German).

11. Annamalai K., Sweeten J.M., Ramalingam S.C. Estimation of grossheating values of biomass fuels. Transaction of the Asae, vol. 30, 1987, pp. 1205-1208.

12. Benetto E., Jury C., Kneip G., Vázquez-Rowe I., Huck V., Minette F. Life cycle assessment of heat production from grape marc pellets. Journal of Cleaner Production, vol. 87, 2015, pp. 149158.

13. Miranda T., Román S., Montero I., Nogales-Delgado S., Arranz J.I., Rojas C.V., González, J.F. Study of the emissions and kinetic parameters during combustion of grape pomace: Dilution as an effective way to reduce pollution. Fuel Processing Technology, vol. 103, 2012, pp. 160-165.

14. Balaman Ş.Y., Selim H. Biomass to Energy Supply Chain Network Design: An Overview of Models, Solution Approaches and Applications. In Handbook of Bioenergy. Springer International Publishing, 2015. pp. 1-35.

15. Larsson S.H., Rudolfsson M. Temperature control in energy grass pellet production-Effects on process stability and pellet quality. Applied Energy, vol. 97, 2012, pp. 24-29.

16. Prozil S.O., Evtuguin D.V., Lopes L.P.C. Chemical composition of grape stalks of Vitis vinifera L. from red grape pomaces. Industrial Crops and Products, vol. 35, 2012, pp. 178-184.

17. Freppaz D., Minciardi R., Robba M., Rovatti M., Sacile R., Taramasso A. Optimizing forest biomass exploitation for energy supply at a regional level. Biomass Bioenergy, vol. 26, 2004, pp. $15-25$.

18. McCormick K., Kåberger T. Key barriers for bioenergy in Europe: economicconditions, knowhow and institutional capacity, and supply chain co-ordination. Biomass Bioenergy, vol. 31, 2007, pp. 443-452. 